\title{
12. SHORE LABORATORY REPORT ON CENOZOIC PLANKTONIC FORAMINIFERA: LEG 33
}

\author{
Yokichi Takayanagi and Motoyoshi Oda, Institute of Geology and Paleontology, \\ Tohoku University, Sendai, Japan
}

\section{INTRODUCTION}

Calcareous sediments from Sites $315,316,317$, and 318 were examined in order to determine the stratigraphic distribution of Cenozoic planktonic foraminifers in cores recovered on Leg 33 of the Deep Sea Drilling Project. These sites are south of the Hawaiian Islands: Sites 315 and 316 located along the Line Islands, Site 317 on the Manihiki Plateau, and Site 318 in an elongate perched basin on the Tuamotu Ridge.

The samples, with a dry weight of 2 to $5 \mathrm{~g}$ were washed on a 200 -mesh sieve (opening: $0.074 \mathrm{~mm}$ ) for foraminiferal study. All species encountered in the respective samples are shown in Tables 1 to 5 , with indications of their relative abundances. The abundance of each species is shown by a letter symbol as follows:

\begin{tabular}{lc}
\hline Relative Abundance & Percent \\
\hline P (Very rare) & $<2$ \\
R (Rare) & $2-4$ \\
C (Common) & $4-16$ \\
A (Abundant) & $16-32$ \\
VA (Very abundant) & $>32$ \\
\hline
\end{tabular}

The number of specimens generally exceeds far more than 400 in each count. However, in the case of samples poor in foraminifers (less than 200 specimens) only presence is indicated by the symbol "+".

\section{LIST OF SPECIES}

Abundant well-preserved planktonic foraminifers, ranging in age from Eocene to Pleistocene occur in the examined cores. As far as classification of the Cenoznic forms is concerned, a noteworthy contribution has recently been made by Fleisher (1974). His classification for foraminiferal genera differs somewhat from those of previous workers, but is thus adopted in this report with some reservations for future work. In order to avoid taxonomic confusion, the full species name, author, and date of original publication are listed below, with an indication of the genus in which the species was originally placed.

Acarinina boudreauxi Fleisher, 1974

Acarinina broedermanni (Cushman and Bermudez, 1949) (ex Globorotalia)

Acarinina mckannai (White, 1928) (ex Globigerina)

Acarinina mattseensis alticonica Fleisher, 1974

Acarinina planodorsalis Fleisher, 1974

Acarinina pseudotopilensis Subbotina, 1953

Acarinina punctocarinata Fleisher, 1974

Acarinina rotundimarginata Subbotina, 1953
Acarinina soldadoensis (Bronnimann, 1952) (ex Globigerina)

Acarinina spinuloinflata (Bandy, 1949) (ex Globigerina) Biorbulina bilobata (d’Orbigny, 1846) (ex Globigerina)

Candeina nitida d'Orbigny, 1839

Cassigerinella chipolensis (Cushman and Ponton, 1932) (ex Cassidulina)

Catapsydrax africanus (Blow and Banner, 1962) (ex Globigerinita)

Catapsydrax dissimilis ciporensis (Blow and Banner, 1962) (ex Globigerinita)

Catapsydrax dissimilis dissimilis (Cushman and Bermudez, 1937) (ex Globigerina)

Catapsydrax globiformis (Blow and Banner, 1962) (ex Globigerinita)

Catapsydrax howei (Blow and Banner, 1962) (ex Globigerinita)

Catapsydrax martini martini (Blow and Banner, 1962) (ex Globigerinita)

Catapsydrax martini scandretti (Blow and Banner, 1962) (ex Globigerinita)

Catapsydrax perus (Todd, 1957) (ex Globigerinita)

Catapsydrax riveroae (Bermudez, 1961) (ex Globigerinita))

Catapsydrax stainforthi Bolli, Loeblich, and Tappan, 1957

Catapsydrax unicavus primitivus (Blow and Banner, 1962) (ex Globigerinita)

Catapsydrax unicavus unicavus Bolli, Loeblich, and Tappan, 1957

"Catapsydrax" echinatus Bolli, 1957

Chiloguembelina cubensis (Palmer, 1934) (ex Guembelina)

Globanomalina pseudoscitula (Glaessner, 1937) (ex Globorotalia)

Globigerina angulisuturalis Bolli, 1957

Globigerina apertura Cushman, 1918

Globigerina bulloides d'Orbigny, 1826

Globigerina calida Paker, 1962

Globigerina decoraperta Takayanagi and Saito, 1962

Globigerina digitata Brady, 1879

Globigerina druryi Akers, 1955

Globigerina falconensis Blow, 1959

Globigerina nepenthes Todd, 1957

Globigerina officinalis Subbotina, 1953

Globigerina ouachitaensis ciperoensis Bolli, 1957

Globigerina ouachitaensis gnaucki Blow and Banner, 1962

Globigerina ouachitaensis ouachitaensis Howe and Wallace, 1932

Globigerina parabulloides Blow, 1959

Globigerina praebulloides leroyi Blow and Banner, 1962

Globigerina praebulloides occlusa Blow and Banner, 1962 
TABLE 1

Distribution of Cenozoic Planktonic Foraminifers, Hole 315A

\begin{tabular}{|c|c|c|c|c|c|c|c|c|c|c|}
\hline Age & & te $M$ & fiocene & & $\begin{array}{l}\text { Mid. } \\
\text { Mio. }\end{array}$ & & Early M & Miocene & & a \\
\hline Zone & & $\bar{z}$ & $z$ & & $\frac{i}{z} \frac{9}{z}$ & $\mid \begin{array}{l}\infty \\
z \\
z\end{array}$ & $\begin{array}{l}b \\
z \\
z\end{array}$ & z & & $\begin{array}{l}\bar{y} \\
\underline{a}\end{array}$ \\
\hline Species & 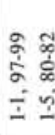 & & 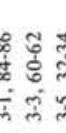 & & 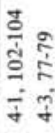 & $\frac{\infty}{\frac{\infty}{b}}$ & & 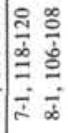 & $\frac{m}{\infty}$ & $\frac{\frac{d}{d}}{d}$ \\
\hline $\begin{array}{l}\text { Biorbulina bilobata } \\
\text { Catapsydrax dissimilis ciperoensis } \\
\text { C. dissimilis dissimilis } \\
\text { C. unicarvus unicarvus } \\
\text { Globigerina angustiumbilicata }\end{array}$ & & $\begin{array}{l}P \\
P\end{array}$ & $P$ & & & & $\mathbf{R}$ & $\begin{array}{ll}\mathrm{P} & \\
\mathrm{P} & \mathrm{P} \\
\mathrm{R} & \mathrm{P} \\
\mathrm{R} & \mathrm{R}\end{array}$ & $\begin{array}{l}\mathrm{P} \\
\mathrm{A}\end{array}$ & $\begin{array}{l}\mathrm{R} \\
\mathrm{V}\end{array}$ \\
\hline $\begin{array}{l}\text { G. decoraperta } \\
\text { G. druryi } \\
\text { G. falconensis } \\
\text { G. nepenthes } \\
\text { G. ouachitaensis ciperoensis }\end{array}$ & $\begin{array}{ll}C & C \\
P_{R}\end{array}$ & & $\mathrm{PCP}$ & & P & & & A & $\mathrm{R}$ & $P$ \\
\hline $\begin{array}{l}\text { G. parabulloides } \\
\text { G. praebulloides leroyi } \\
\text { G. praebulloides praebulloides } \\
\text { G. woodi } \\
\text { Globigerinatella insueta }\end{array}$ & & & & & $\mathrm{R}$ & P & & ${ }^{\mathrm{R}} \mathrm{C}$ & & $P$ \\
\hline $\begin{array}{l}\text { Globigerinella siphonifera siphonifera } \\
\text { Globigerinita giutinata } \\
\text { G. uvula } \\
\text { Globigerinoides bollii } \\
\text { G. extremus }\end{array}$ & $\begin{array}{ll}\mathrm{P} & \\
\mathrm{C} & \mathrm{C} \\
& \mathrm{P} \\
& \end{array}$ & $\begin{array}{l}\mathrm{P} \\
\mathrm{C} \\
\mathrm{P} \\
\mathrm{P} \\
\mathrm{P}\end{array}$ & 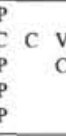 & & $\begin{array}{ll}C & C \\
& P\end{array}$ & $\mathbf{R}$ & $\begin{array}{l}+\mathrm{A} \\
+\mathrm{C}\end{array}$ & $\begin{array}{ll}\text { V } & \text { C } \\
\text { C } & \end{array}$ & $\begin{array}{l}\mathrm{C} \\
\mathrm{P}\end{array}$ & \\
\hline $\begin{array}{l}\text { G. gomitulus } \\
\text { G. obliquus } \\
\text { G. quadrilobatus immaturus } \\
\text { G. quadrilobatus primordius } \\
\text { G. quadrilobatus sacculifer }\end{array}$ & $\begin{array}{l}\mathrm{P} \\
\mathrm{P}\end{array}$ & $\begin{array}{ll}P & \\
P & P \\
P\end{array}$ & $\begin{array}{lll}\mathrm{P} & \mathrm{P} \\
\mathrm{P} & \mathrm{P} \\
\mathrm{C} & \mathrm{P} & \mathrm{F}\end{array}$ & & R P & & & & P & \\
\hline $\begin{array}{l}\text { G. quadrilobatus trilobus } \\
\text { G. subquadratus } \\
\text { Globoquadrina altispira altispira } \\
\text { G. altispira globosa } \\
\text { G. deshicens advena } \\
\end{array}$ & $\begin{array}{ll}\mathrm{R} & \mathrm{P} \\
\mathrm{C} & \mathrm{C} \\
\mathrm{C} & \mathrm{P} \\
\mathrm{C} & \mathrm{R}\end{array}$ & $\begin{array}{ll}P & R \\
C & R \\
P & R \\
R & R\end{array}$ & $\begin{array}{ll}\mathrm{P} & \mathrm{P} \\
\mathrm{R} & \mathrm{P} \\
\mathrm{C} & \mathrm{C} \\
\mathrm{R} & \mathrm{P} \\
\end{array}$ & & $\begin{array}{ll}\text { C } & p \\
& p \\
\text { C } & A\end{array}$ & $\begin{array}{l}P \\
P \\
P\end{array}$ & $\begin{array}{l}+ \\
+\mathrm{c}\end{array}$ & & & \\
\hline $\begin{array}{l}\text { G. dehiscens dehiscens } \\
\text { G. dehiscens praedehiscens } \\
\text { G. galavisi } \\
\text { G. tripartita tripartita } \\
\text { G. venezuelana }\end{array}$ & $\begin{array}{l}\mathrm{P} \\
\mathrm{P}\end{array}$ & P C & $C \mathrm{C} R$ & $\mathrm{P}$ & P C & $R$ & $\begin{array}{r}\mathrm{P} \\
+\quad \mathrm{C}\end{array}$ & $\begin{array}{ll} & \\
& \\
\text { C } & \text { P }\end{array}$ & $\begin{array}{l}\mathrm{P} \\
\mathrm{C}\end{array}$ & P \\
\hline $\begin{array}{l}\text { Globorotalia acostaensis } \\
\text { G. birnageae } \\
\text { G. contimuosa } \\
\text { G. cultrata } \\
\text { G. fohsi fohsi }\end{array}$ & $\begin{array}{ll}\text { C } & P \\
P & C\end{array}$ & $\begin{array}{l}\text { P A } \\
\text { C C }\end{array}$ & $\mathrm{C} \quad \mathrm{P}$ & & $\begin{array}{ll}A & C \\
P & \end{array}$ & $\begin{array}{l}\mathrm{V} \\
\mathrm{C}\end{array}$ & & & & \\
\hline $\begin{array}{l}\text { G. fohsi lobata } \\
\text { G. kugleri } \\
\text { G. lenguaensis } \\
\text { G. merotumida } \\
\text { G. miozea cibaoensis }\end{array}$ & C & $\begin{array}{l}\mathrm{P} \\
\mathrm{P}\end{array}$ & $R$ & & $\begin{array}{l}\mathrm{P} \\
\mathrm{R}\end{array}$ & & P. & C V & A & \\
\hline $\begin{array}{l}\text { G. obesa } \\
\text { G. opima nana } \\
\text { G. opima opima } \\
\text { G. peripheroacuta } \\
\text { G. peripheroronda }\end{array}$ & P & P & & & R P & & + & $\mathbf{P}$ & C & R \\
\hline $\begin{array}{l}\text { G. prasaepis } \\
\text { G. pseudokugleri } \\
\text { G. siakensis } \\
\text { G. cf. siakensis } \\
\text { G. tumida plesiotumida }\end{array}$ & P & $\mathrm{R}$ & $2 \mathrm{CC}$ & & $\begin{array}{ll}\mathrm{V} & \mathrm{A} \\
\mathrm{C} & \mathrm{C}\end{array}$ & $\begin{array}{l}\mathrm{C} \\
\mathrm{P}\end{array}$ & $\begin{array}{l}+\mathrm{A} \\
+\mathrm{A}\end{array}$ & $\begin{array}{ll} & \text { P } \\
\text { C } & \text { C } \\
& \text { R }\end{array}$ & $\begin{array}{l}\mathrm{C} \\
\mathrm{R}\end{array}$ & $\begin{array}{l}\mathrm{R} \\
\mathrm{C} \\
\mathrm{V}\end{array}$ \\
\hline $\begin{array}{l}\text { Globorotaloides hexagonus } \\
\text { G. suteri } \\
\text { G. valiabilis } \\
\text { Orbulina suturalis } \\
\text { O. universa }\end{array}$ & P $\quad$ P & R & $\begin{array}{l}\mathrm{P} \\
\mathrm{P} \\
\mathrm{P}\end{array}$ & & & & + & $\begin{array}{ll}C & P \\
P & \end{array}$ & & R \\
\hline $\begin{array}{l}\text { Pulleniatina primalis } \\
\text { Sphaeroidinellopsis seminulina semimulina } \\
\text { S. subdehiscens } \\
\text { Subbotina gortanii gortanii } \\
\text { Tenuitella clemenciae } \\
\text { T. praestainforthi }\end{array}$ & $\begin{array}{ll}\mathrm{R} & \mathrm{P} \\
\mathrm{R} & \mathrm{C} \\
\mathrm{P} & \mathrm{A}\end{array}$ & $\left\{\begin{array}{l}P \\
P \\
C\end{array}\right.$ & $\begin{array}{ll}\mathrm{C} & \mathrm{P} \\
\mathrm{C} & \mathrm{R}\end{array}$ & & $\begin{array}{ll}R & R \\
R & P\end{array}$ & & + & $P$ & & \\
\hline
\end{tabular}

${ }^{\text {a OOligocene. }}$
TABLE 2

Distribution of Cenozoic Planktonic Foraminifers, Site 316

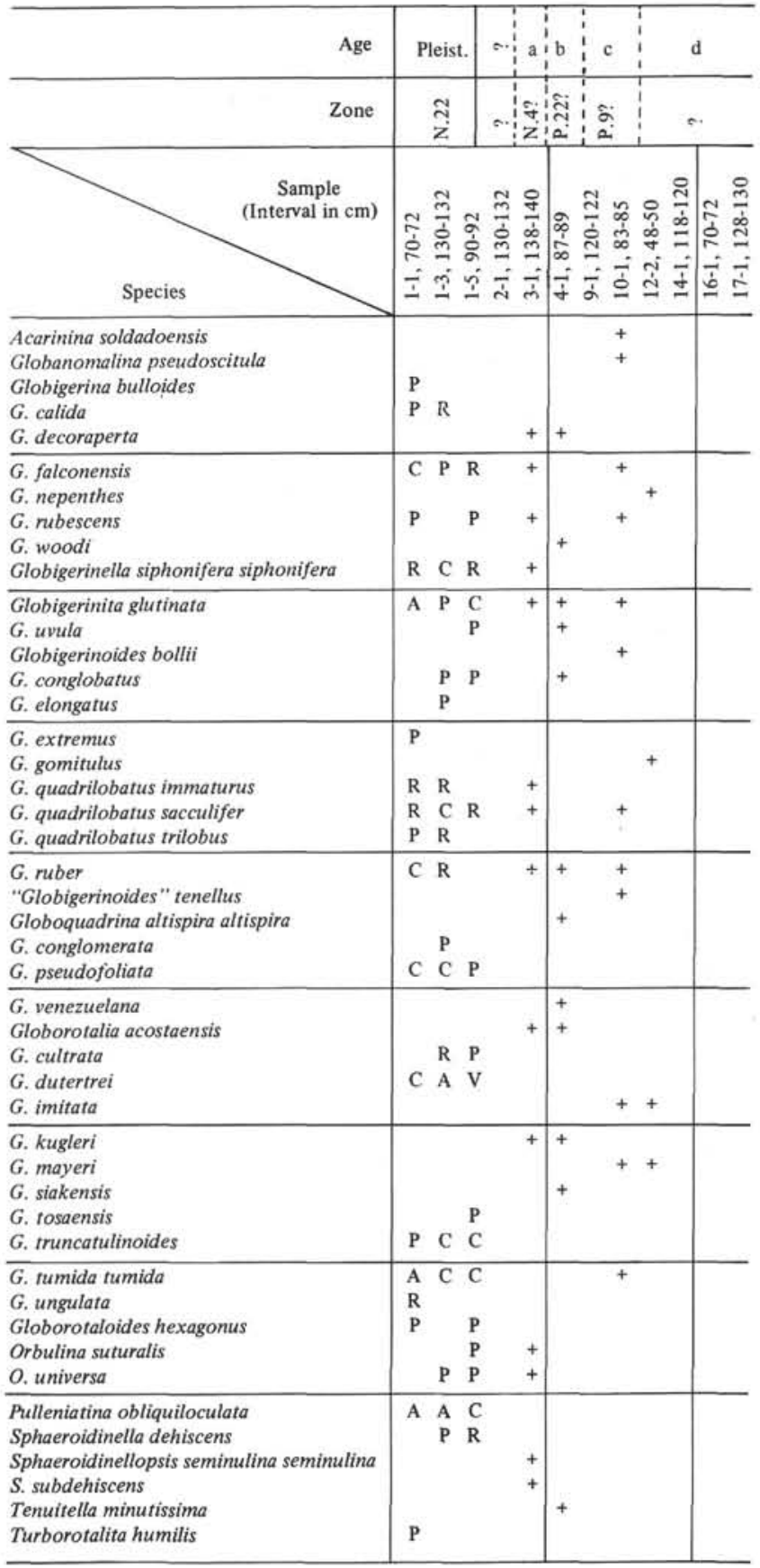

${ }^{\mathrm{a}}$ Early Miocene.

boligocene.

${ }^{c}$ Early Eocene.

${ }^{\mathrm{d}}$ Paleocene?

Globigerina praebulloides praebulloides Blow, 1959

Globigerina praedigitata Parker, 1967

Globigerina rubescens Hofker, 1956

Globigerina woodi Jenkins, 1960

Globigerinatella insueta Cushman and Stainforth, 1945

Globigerinatheka index index (Finlay, 1939) (ex Globigerinoides) 
TABLE 3

Distribution of Cenozoic Planktonic Foraminifers, Hole 317

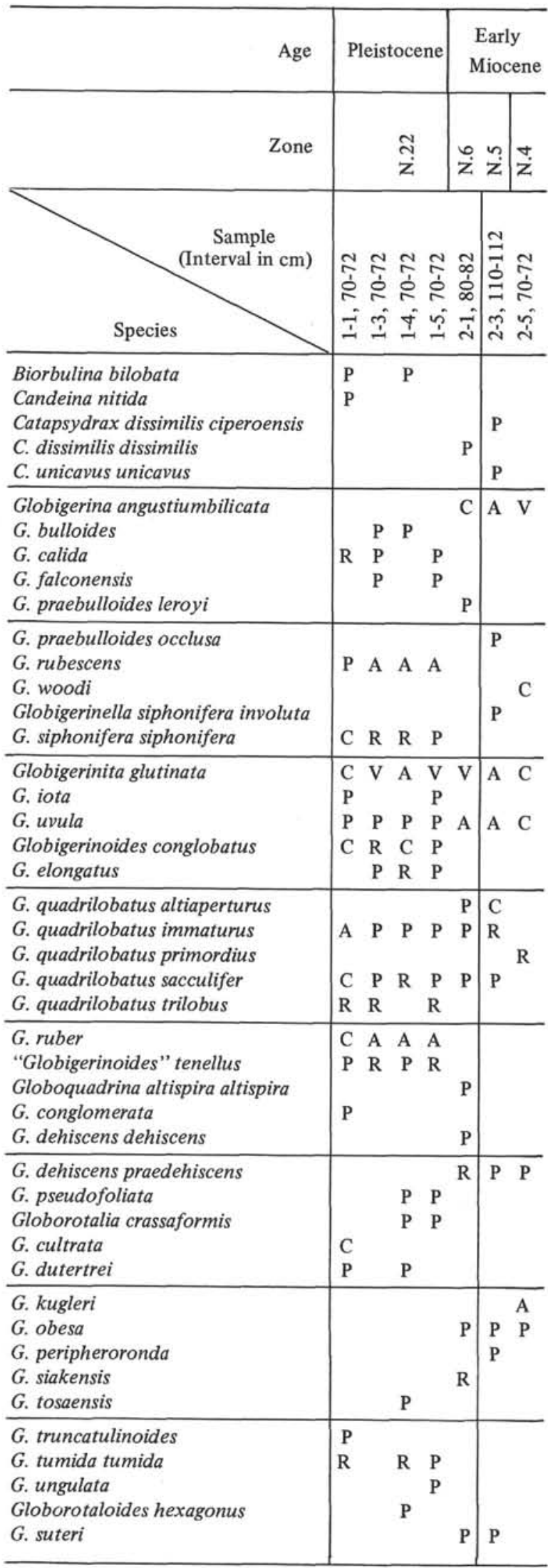

TABLE 3 - Continued

\begin{tabular}{|c|c|c|c|c|}
\hline Age & Pleistocen & $\begin{array}{r}\mathrm{E} \\
\mathrm{Mi}\end{array}$ & $\begin{array}{l}\text { Early } \\
\text { lioce }\end{array}$ & \\
\hline Zone & $\underset{\text { त̂ }}{z}$ & $\begin{array}{l}0 \\
z\end{array}$ & $\stackrel{n}{z}$ & z \\
\hline (Interval in cm) & 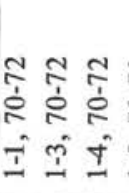 & 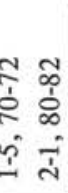 & 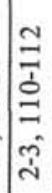 & 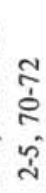 \\
\hline $\begin{array}{l}\text { Orbulina suturalis } \\
\text { O. universa } \\
\text { Pulleniatina obliquiloculata } \\
\text { Sphaeroidinella dehiscens } \\
\text { Subbotina gortanii gortanii }\end{array}$ & $\begin{array}{lll}\mathrm{P} & & \\
\mathrm{C} & \mathrm{R} & \mathrm{C} \\
\mathrm{R} & & \mathrm{P} \\
\mathrm{P} & & \mathrm{R}\end{array}$ & & $\mathbf{P}$ & \\
\hline $\begin{array}{l}\text { Tenuitella anfracta } \\
\text { T. clemenciae } \\
\text { T. minutissima } \\
\text { Turborotalita humilis } \\
\text { T. praepumilio }\end{array}$ & $\begin{array}{l}P \\
P\end{array}$ & $\mathbf{P}$ & $P$ & P \\
\hline
\end{tabular}

Globigerinatheka index tropicalis (Blow and Banner, 1962) (ex Globigerapsis)

Globigerinatheka mexicana barri Brönnimann, 1952

Globigerinatheka mexicana kugleri (Bolli, Loeblich, and Tappan, 1957) (ex Globigerapsis)

Globigerinatheka mexicana mexicana (Cushman, 1925) (ex Globigerina)

Globigerinatheka semiinvoluta (Keijzer, 1945) (ex Globigerinoides)

Globigerinatheka senni (Beckmann, 1953) (ex Sphaeroidinella)

Globigerinatheka subconglobata curryi Proto Decima and Bolli, 1970

Globigerinatheka subconglobata luterbacheri Bolli, 1972 Globigerinatheka subconglobata subconglobata (Chalilov, 1958) (ex Globigerinoides)

Globigerinella siphonifera involuta (Cushman, 1917) (ex Globigerina)

Globigerinella siphonifera siphonifera (d'Orbigny, 1839)

(ex Globigerina)

Globigerinita glutinata Egger, 1893) (ex Globigerina)

Globigerinita iota Parker, 1962

Globigerinita uvula (Ehrenberg, 1861) (ex Pylodexia)

Globigerinoides bollii Blow, 1959

Globigerinoides conglobatus (Brady, 1879) (ex Globigerina)

Globigerinoides elongatus (d'Orbigny, 1926) (ex Globigerina)

Globigerinoides extremus Bolli and Bermudez, 1965

Globigerinoides gomitulus (Seguenza, 1880) (ex Globigerina)

Globigerinoides obliquus Bolli, 1957

Globigerinoides quadrilobatus altiaperturus Bolli, 1957

Globigerinoides quadrilobatus fistulosus (Schubert, 1910)

(ex Globigerina)

Globigerinoides quadrilobatus immaturus LeRoy, 1939 
TABLE 4

Distribution of Cenozoic Planktonic Foraminifers, Hole 317B

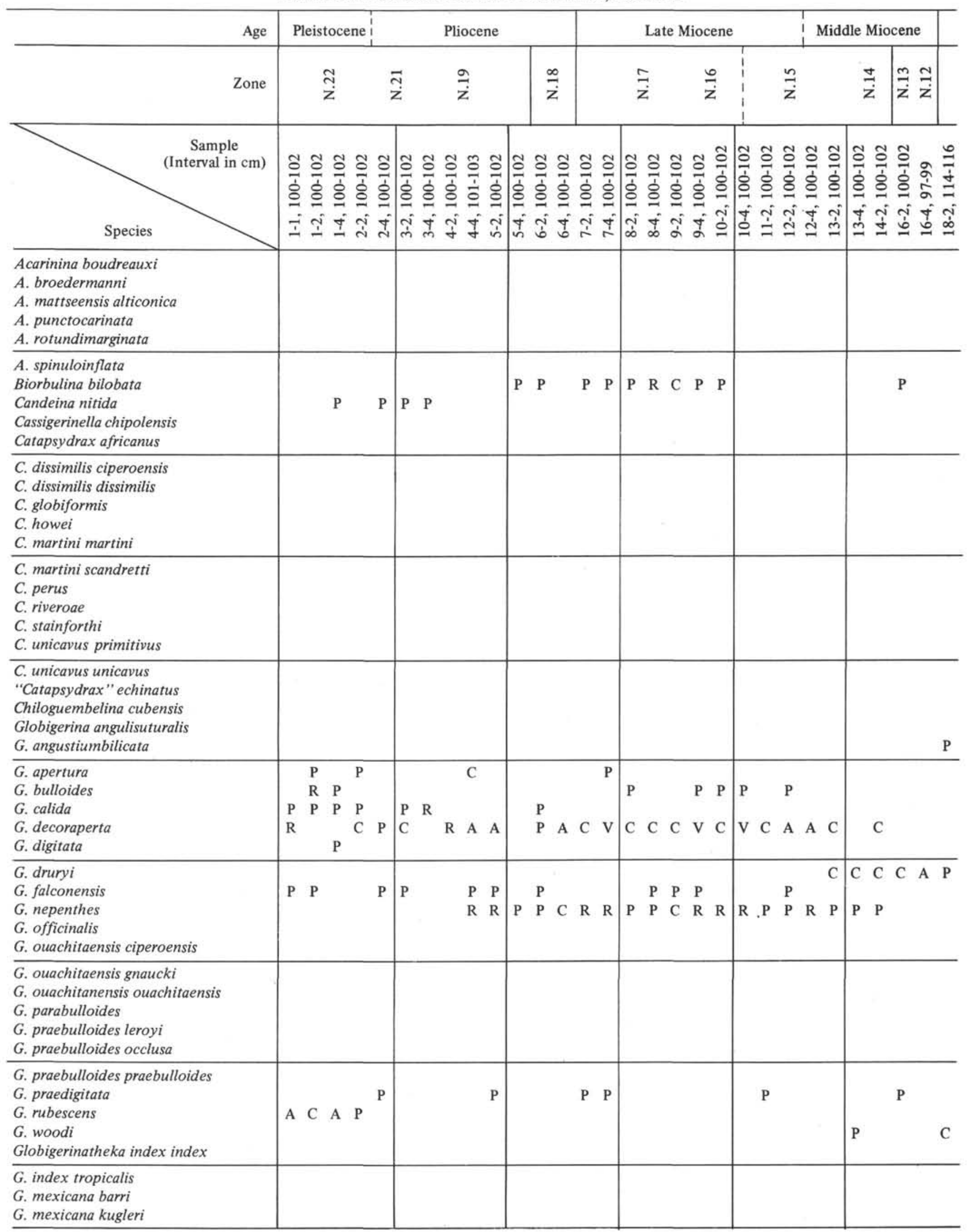


TABLE 4 - Continued

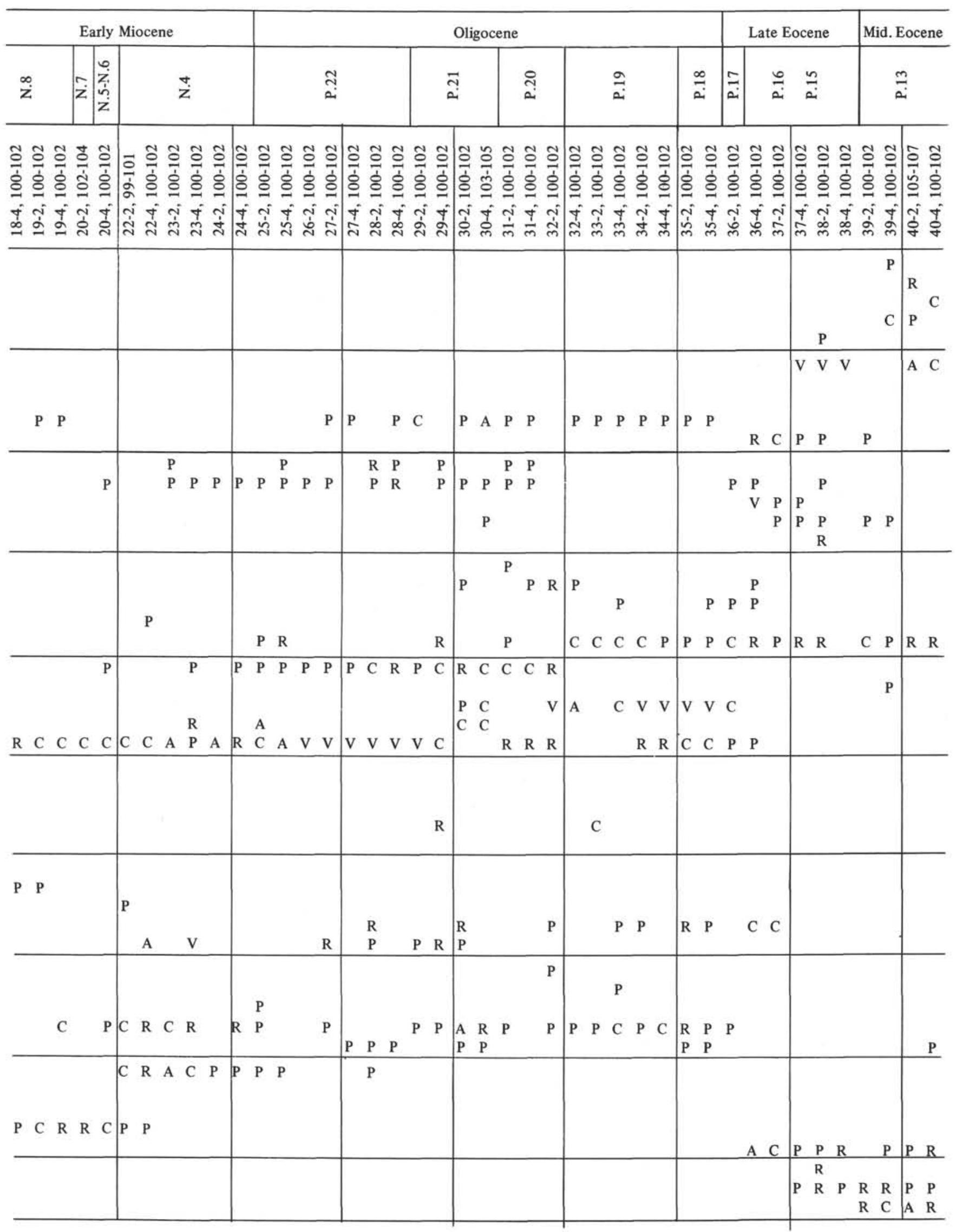


TABLE 4 - Continued

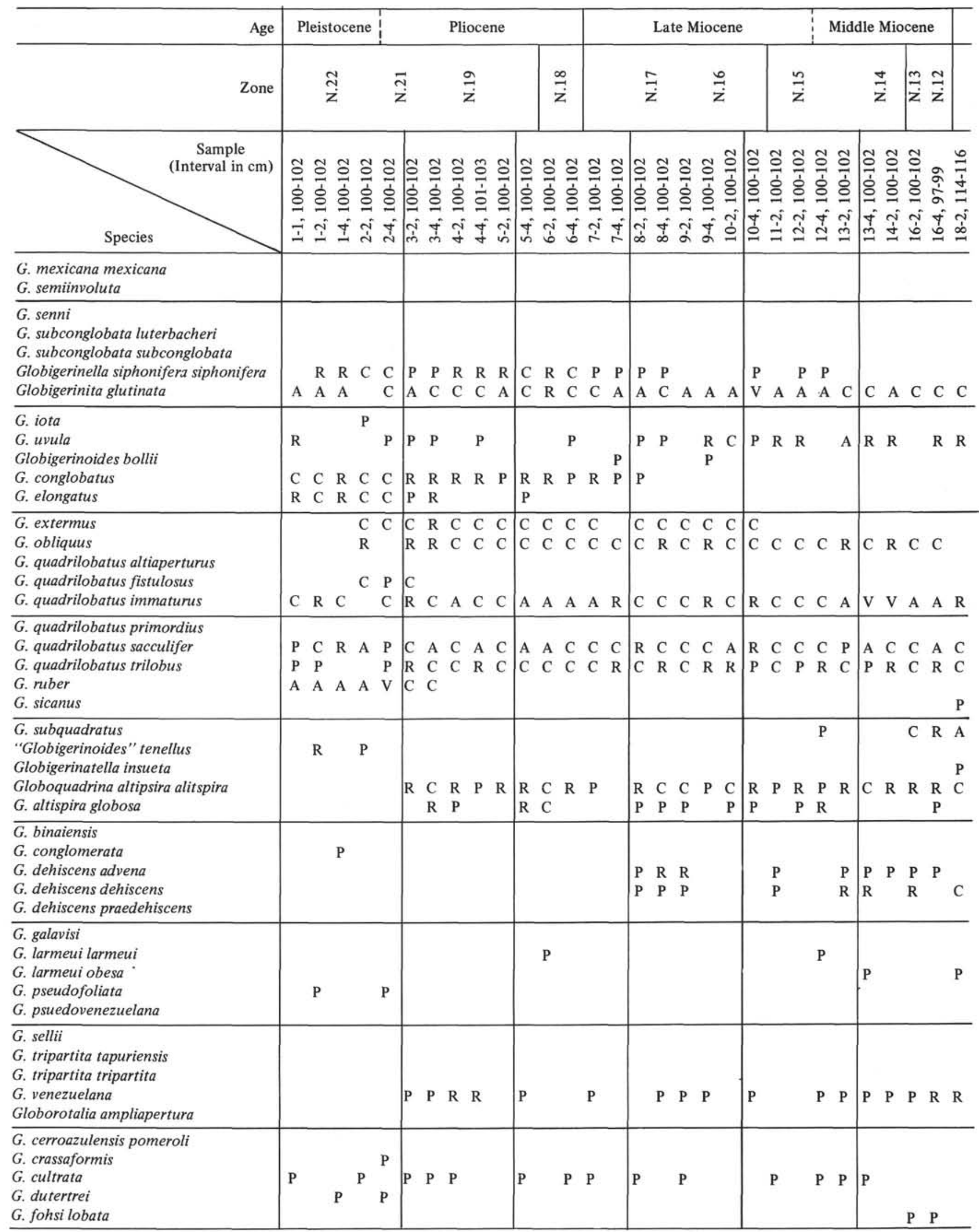


CENOZOIC PLANKTONIC FORAMINIFERA

TABLE 4 - Continued

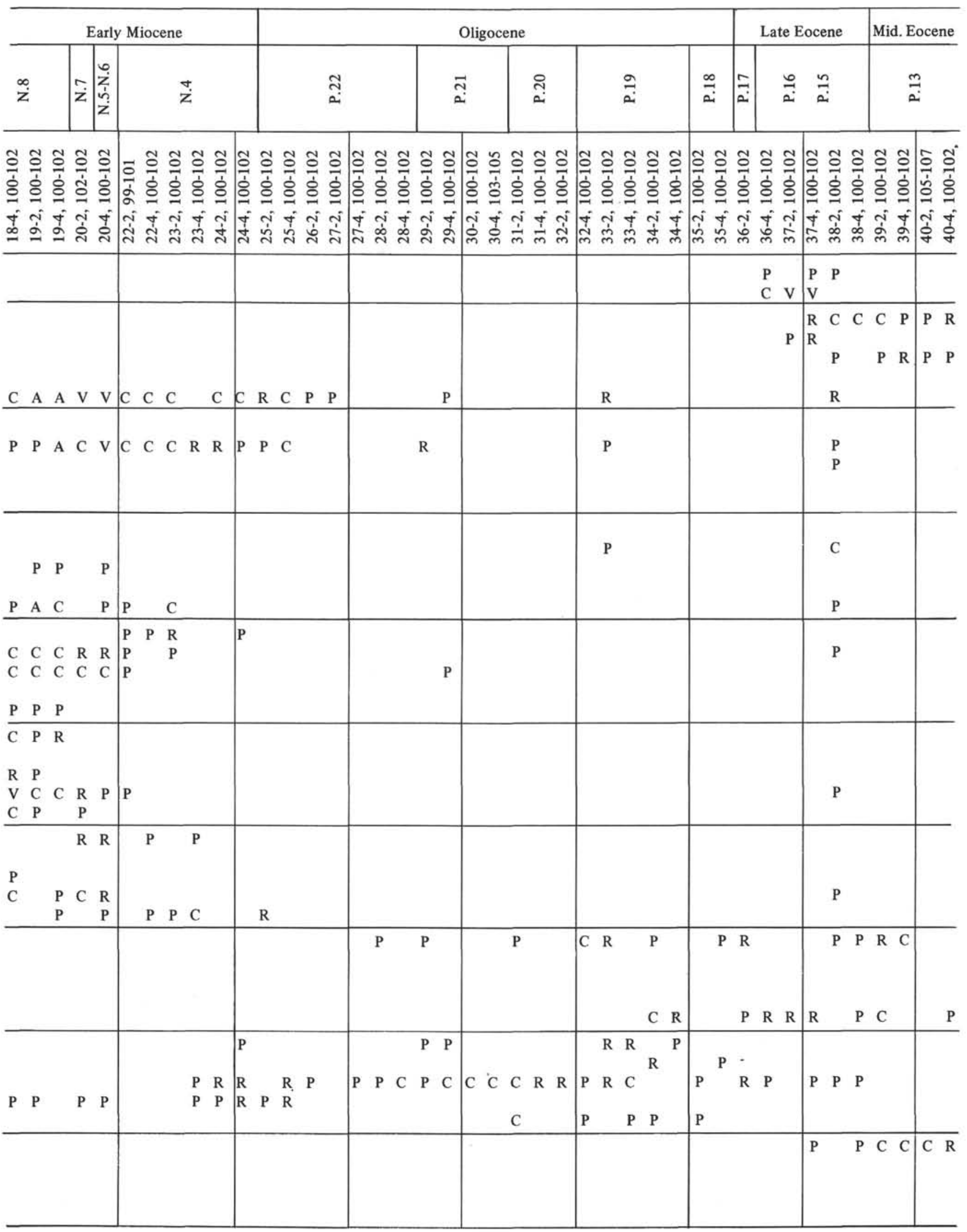


TABLE 4 - Continued

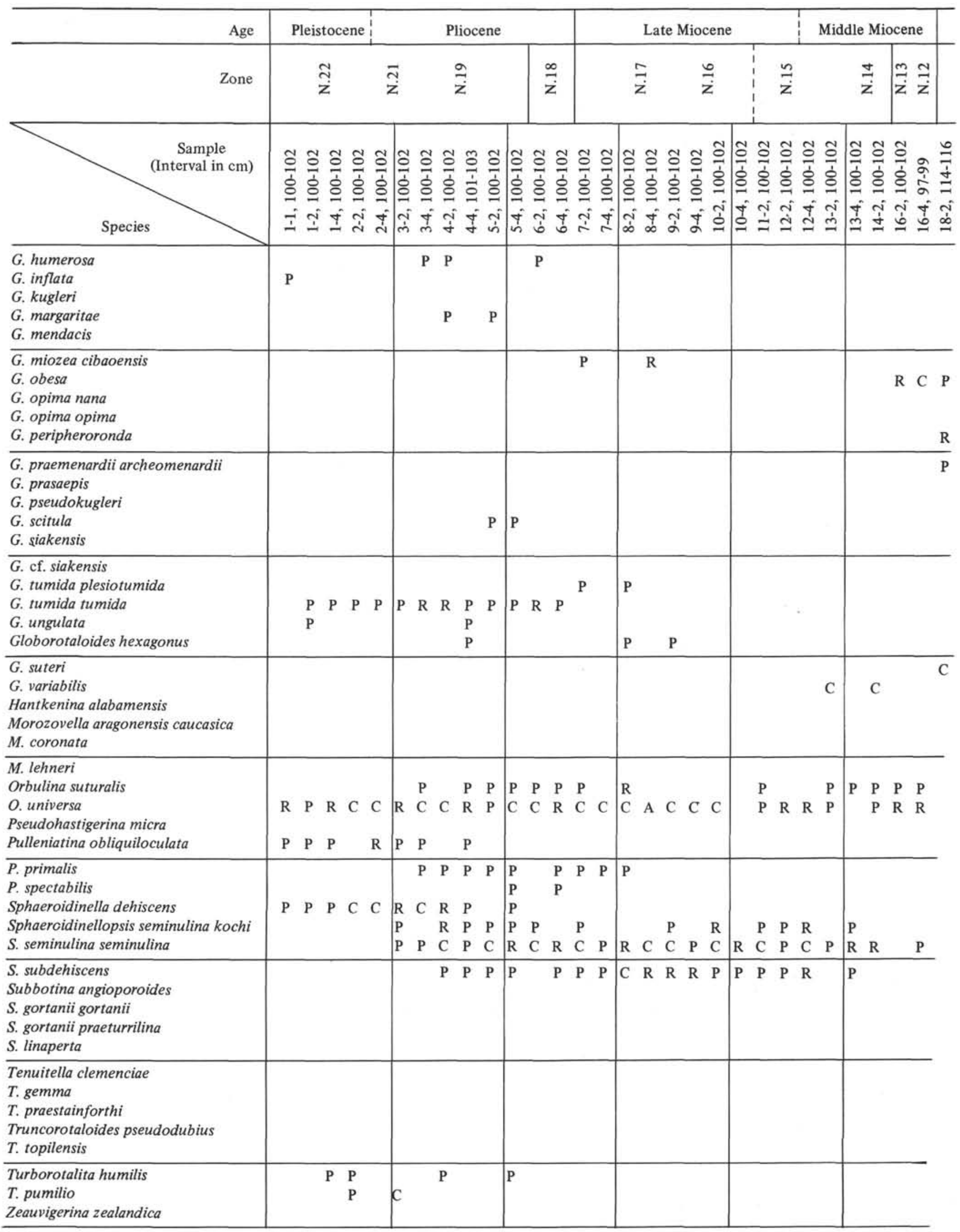


TABLE 4 - Continued

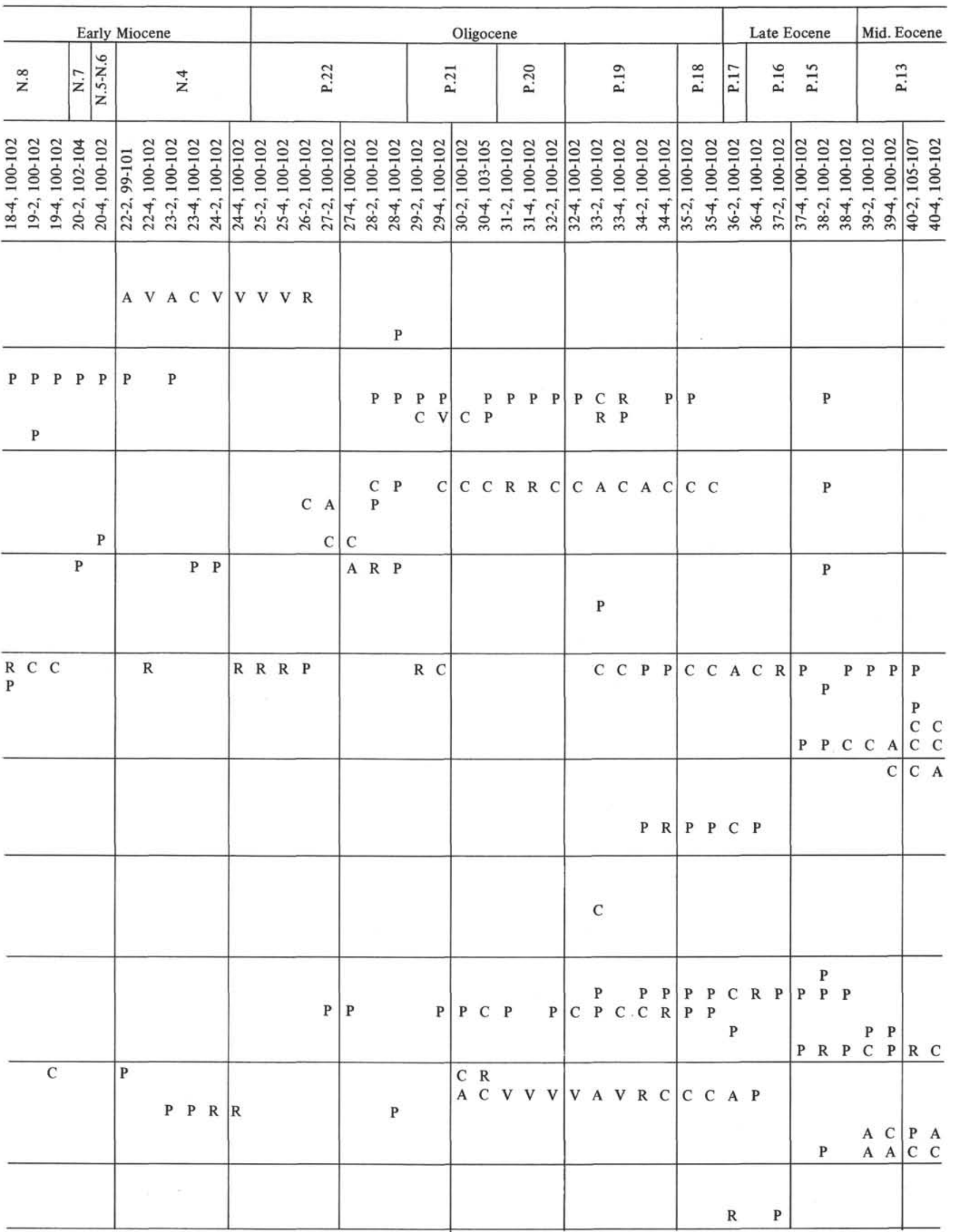


TABLE 5

Distribution of Cenozoic Planktonic Foraminifers, Site 318

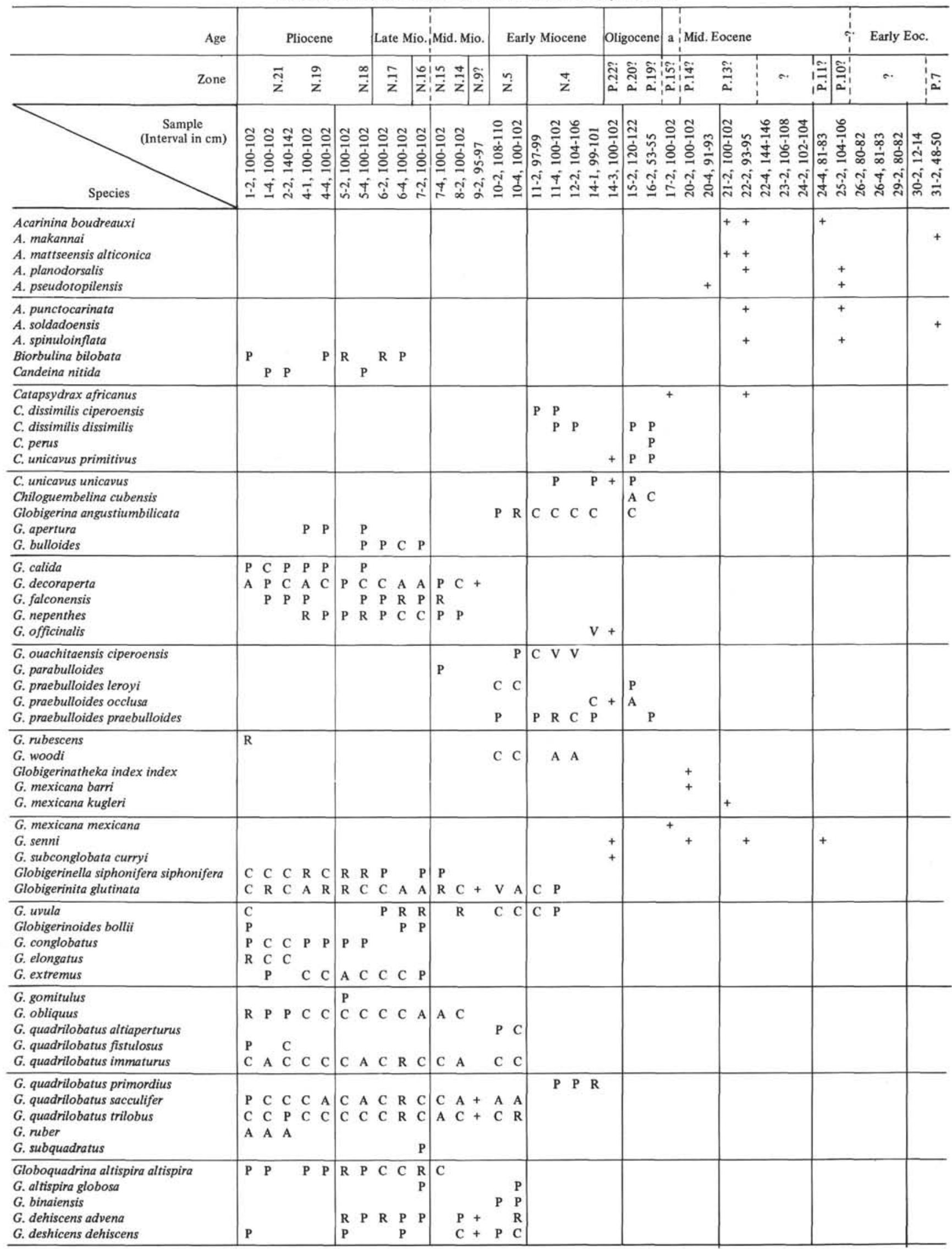


TABLE 5 - Continued

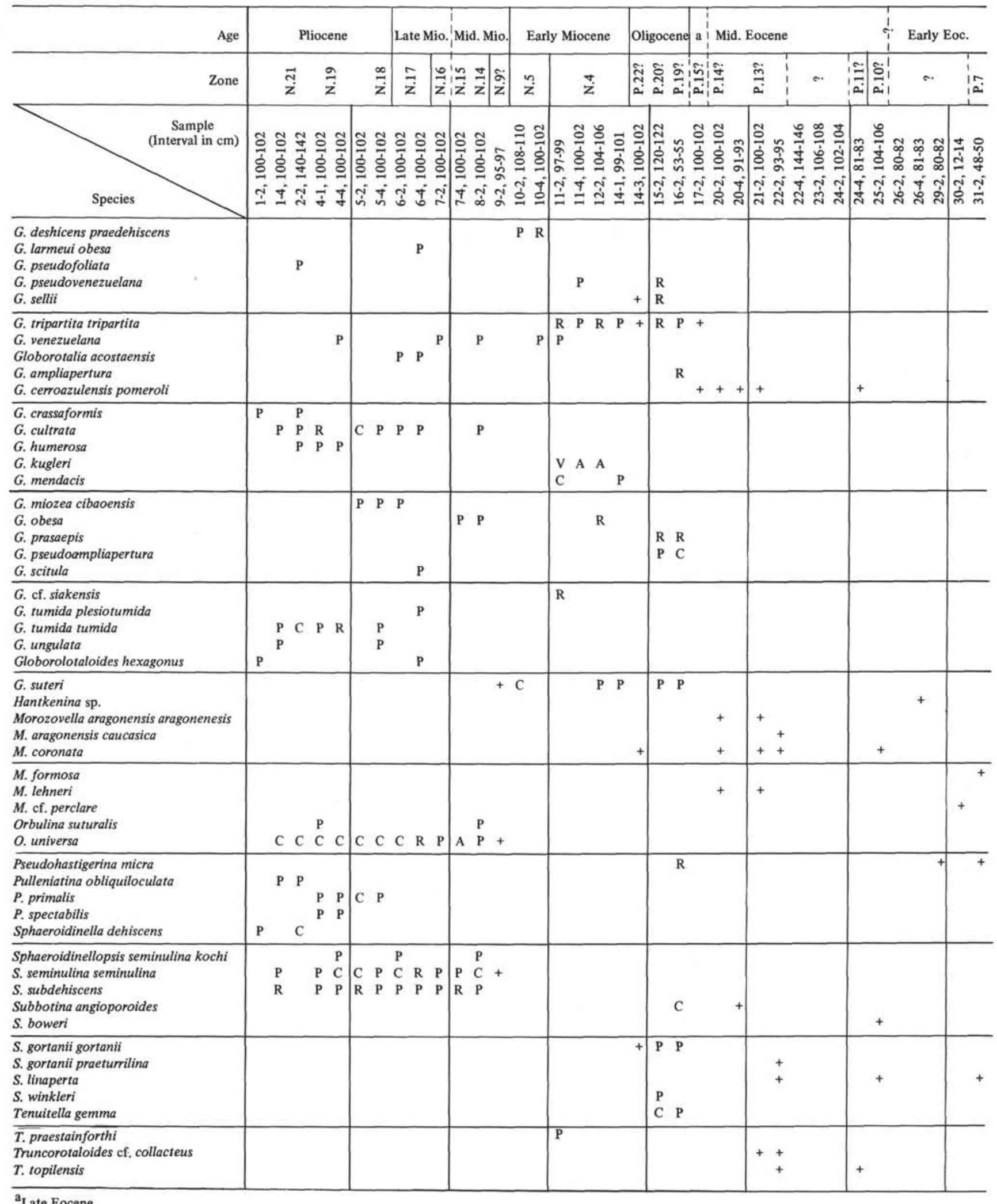


Globigerinoides quadrilobatus primordius Blow and Banner, 1962

Globigerinoides quadrilobatus sacculifer (Brady, 1877) (ex Globigerina)

Globigerinoides quadrilobatus trilobus (Reuss, 1850) (ex Globigerina)

Globigerinoides ruber (d'Orbigny, 1839) (ex Globigerina)

Globigerinoides sicanus de Stefani, 1952

Globigerinoides subquadratus Brönnimann, 1954

"Globigerinoides" tenellus Parker, 1958

Globoquadrina altispira altispira (Cushman and Jarvis, 1936) (ex Globigerina)

Globoquadrina altispira globosa Bolli, 1957

Globoquadrina binaiensis (Koch, 1935) (ex Globigerina)

Globoquadrina conglomerata (Schwager, 1866) (ex

Globigerina)

Globoquadrina dehiscens advena Bermudez, 1959

Globoquadrina dehiscens dehiscens (Chapman, Parr, and Collins, 1938) (ex Globorotalia)

Globoquadrina dehiscens praedehiscens Blow and Banner, 1962

Globoquadrina galavisi (Bermudez, 1961) (ex Globigerina)

Globoquadrina larmeui larmeui Akers, 1955

Globoquadrina larmeui obesa Akers, 1955

Globoquadrina pseudofoliata Parker, 1967

Globoquadrina pseudovenezuelana (Blow and Banner, 1962) (ex Globigerina)

Globoquadrina sellii Borsetti, 1959

Globoquadrina tripartita tapuriensis (Blow and Banner, 1962) (ex Globigerina)

Globoquadrina tripartita tripartita (Koch, 1926) (ex Globigerina)

Globoquadrina venezuelana (Hedberg, 1937) (ex Globigerina)

Globorotalia acostaensis Blow, 1959

Globorotalia ampliapertura (Bolli, 1957) (ex Globigerina)

Globorotalia birnageae Blow, 1959

Globorotalia cerroazulensis pomeroli Toumarkine and Bolli, 1970

Globorotalia continuosa Blow, 1959

Globorotalia crassaformis (Galloway and Wissler, 1927) (ex Globigerina)

Globorotalia cultrata (d'Orbigny, 1826) (ex Rotalia)

Globorotalia dutertrei (d'Orbigny, 1839) (ex Globigerina)

Globorotalia fohsi fohsi Cushman and Ellisor, 1939

Globorotalia fohsi lobata Bermudez, 1949

Globorotalia humerosa Takayanagi and Saito, 1962

Globorotalia inflata (d'Orbigny, 1839) (ex Globigerina)

Globorotalia imitata Subbotina, 1953

Globorotalia kugleri Bolli, 1957

Globorotalia lenguaensis Bolli, 1957

Globorotalia margaritae Bolli and Bermudez, 1965

Globorotalia mendacis Blow, 1969

Globorotalia merotumida Blow and Banner, 1965

Globorotalia miozea cibaoensis Bermudez, 1949

Globorotalia obesa Bolli, 1957

Globorotalia opima nana Bolli, 1957

Globorotalia opima opima Bolli, 1957

Globorotalia peripheroacuta Blow and Banner, 1966

Globorotalia peripheroronda Blow and Banner, 1966

Globorotalia praemenardii archeomenardii Bolli, 1957
Globorotalia prasaepis (Blow, 1969) (ex Globigerina) Globorotalia pseudoampliapertura (Blow and Banner, 1962) (ex Globigerina)

Globorotalia pseudokugleri Blow, 1969

Globorotalia scitula (Brady, 1882) (ex Pulvinulina)

Globorotalia siakensis LeRoy, 1939

Globorotalia tosaensis Takayanagi and Saito, 1962

Globorotalia truncatulinoides (d'Orbigny, 1839) (ex ?Rotalia)

Globorotalia tumida plesiotumida Blow and Banner, 1965

Globorotalia tumida tumida (Brady, 1377) (ex Pulvinulina)

Globorotalia ungulata Bermudez, 1961

Globorotaloides hexagonus (Natland, 1839) (ex Globigerina)

Globorotaloides suteri Bolli, 1957

Globorotaloides variabilis Bolli, 1957

Hantkenina alabamensis Cushman, 1925

Morozovella aragonensis aragonensis (Nuttall, 1930) (ex Globorotalia)

Morozovella aragonensis caucasica (Glaessner, 1937) (ex Globorotalia)

Morozovella coronata Blow (MS: after Fleisher, 1974)

Morozovella formosa formosa Bolli, 1957) (ex Globorotalia)

Morozovella lehneri (Cushman and Jarvis, 1929) (ex Globorotalia)

Morozovella cf. perclara (Loeblich and Tappan, 1957) (ex Globorotalia)

Orbulina suturalis Brönnimann, 1951

Orbulina universa d'Orbigny, 1839

Pseudohastigerina micra (Cole, 1927) (ex Nonion)

Pulleniatina obliquiloculata (Parker and Jones, 1865) (ex

Pullenia)

Pulleniatina primalis Banner and Blow, 1967

Pulleniatina spectabilis Parker, 1965

Sphaeroidinella dehiscens Parker and Jones, 1865) (ex Sphaeroidina)

Sphaeroidinellopsis seminulina kochi (Caudri, 1934) (ex Globigerina)

Sphaeroidinellopsis seminulina seminulina (Schwager, 1866) (ex Globigerina)

Sphaeroidinellopsis subdehiscens (Blow, 1959) (ex Sphaeroidinella)

Subbotina angiporoides (Hornibrook, 1965) (ex Globigerina)

Subbotina boweri (Bolli, 1957) (ex Globigerina)

Subbotina gortanii gortanii (Borsetti, 1959) (ex Catapsydrax)

Subbotina gortanii praeturritilina (Blow and Banner, 1962) (ex Globigerina)

Subbotina linaperta (Finlay, 1939) (ex Globigerina)

Subbotina winkleri (Bermudez, 1961) (ex Globigerina)

Tenuitella anfracta (Parker, 1967) (ex Globorotalia)

Tenuitella clemenciae (Bermudez, 1961) (ex Turborotalia)

Tenuitella gemma (Jenkins, 1966) (ex Globorotalia)

Tenuitella praestainfohsi (Blow, 1969) (ex Globigerinita) Truncorotaloides pseudodubius (Bandy, 1949) (ex Globigerinoides)

Truncorotaloides topilensis (Cushman, 1925) (ex Globigerina) 


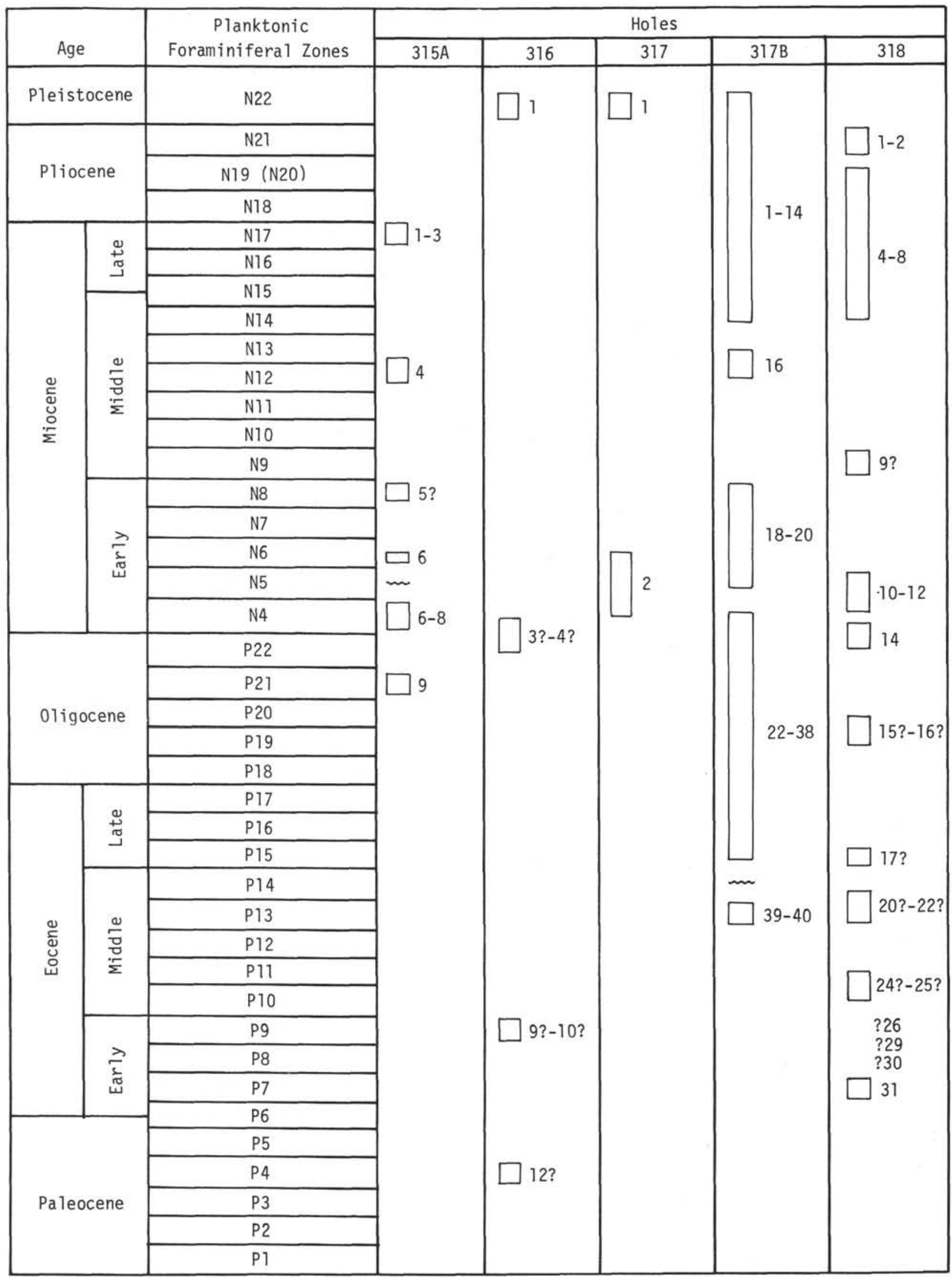

Figure 1. Cenozoic sediments cored on Leg 33. Only foraminifer-bearing cores are shown in the figure. Cores are represented by numbered rectangles; cores for which ages are indeterminable are not accompanied by rectangles. 
Truncorotaloides cf. collacteus (Finlay, 1939) (ex Globorotalia)

Turborotalita humilis (Brady, 1884) (ex Truncatulina)

Turborotalita pumilio (Parker, 1962) (ex Globorotalia)

Zeauvigerina zealandica Finlay, 1939

\section{RESULTS}

\section{Site 315 (lat $04^{\circ} 10.26^{\prime} \mathrm{N}$, long $158^{\circ} 31.54^{\prime} \mathrm{W}$, depth 4162} m)

Only cores 1 to 9 from Hole 315A were examined. Traces of dissolution are more or less observed in all samples, but none is strongly affected. In the sample from Section 1 of Core 6 the number of specimens is meager due to difficulty in the maceration procedure. A stratigraphic break is suggested between Sections 1 and 3 of Core 6. The uppermost occurrence of Globorotalia kugleri is marked in Section 3, while Section 1 is characterized by the lowermost occurrence of Globorotalia peripheroronda and Sphaeroidinellopsis seminulina seminulina. This break may include Zone N.5. Except for Core 9, for which an Oligocene age is suggested, the stratigraphic sequence of Cores 1 through 8 represents the Miocene (Zones N.4 to N.17).

\section{Site 316 (lat $00^{\circ} 05.44^{\prime} \mathrm{N}$, long $157^{\circ} 07.71^{\prime} \mathrm{W}$, depth 4464 m)}

Twelve samples were examined from Cores 1 through 17 at Site 316. A well-preserved assemblage of Pleistocene age (Zone N.22) occurs in Core 1. Heavy dissolution characterizes the rest of the cores and a number of species in these cores are judged to have been brought in through downhole contamination. The presence of Globorotalia kugleri in Cores 3 and 4 suggests that they belong in Zones P.22 to N.4. The Oligocene/Miocene boundary is tentatively drawn between Cores 3 and 4 . The very poor state of preservation in Cores 9 to 17 makes age assignment very difficult. Diagnostic Paleogene species (Acarinina soldadoensis, Globanomalina pseudoscetula, and Globorotalia imitata) are found in association with several Neogene forms in Core 10 , but $\mathrm{G}$. imitata is the only Paleogene form in the underlying Core 12. Although the Paleocene/Eocene boundary is provisionally placed between these levels, further investigation is needed for precise age determination.

\section{Site 317 (lat $11^{\circ} 00.09^{\prime} \mathrm{S}$, long $162^{\circ} 15.78^{\prime} \mathrm{W}$, depth 2625 m)}

Samples were examined from Holes 317 and 317B. Cores 1 and 2 of Hole 317 are assigned to the Pleistocene and lower Miocene, respectively, Cores 1 through 40 represent almost continuous coring in Hole $317 \mathrm{~B}$, and they encompass a fairly complete sequence from the Pleistocene to the middle Eocene. In comparison with cores from other sites of Leg 33, preservation of specimens is exceptionally good. Dissolution is not as pronounced, even in Eocene assemblages (Cores 32 to 40). A trace of contamination is obvious at some levels within the Paleogene.

Core 1 of Hole 317 and Cores 1 and 2 (only the upper part) of Hole 317B contain Pleistocene assemblage (Zone N.22). Because of the absence of Globorotalia truncatulinoides, the Pliocene/Pleistocene (Zone N.21/N.22) boundary is not clearly specified. However, an approximate boundary is estimated between Sections 2 and 4 of Core 2, based on the lowermost occurrence of "Globigerinoides" tenellus and the uppermost occurrence of Globigerinoides quadrilobatus fistulosus near the N.21/N.22 boundary. The N.18/N.19 boundary, defined by the first occurrence of Sphaeroidinella dehiscens lies between Cores 5 and 6. The Miocene/Pliocene boundary is here placed at the level of the first occurrence of Globorotalia tumida tumida (base of Zone N.18), although opinion on this placement is divided. Regarding this boundary, Berggren (1973) considers that the extinction level of Globoquadrina dehiscens, together with $G$. tumida tumida appearance datum, is a reliable indicator. In the present sequence, however, a distinct gap is recognized between these two datums; $G$. tumida tumida appears first in Core 6, while the last occurrence of $G$. dehiscens is recorded in Core 8 .

Cores 7 to 10 are referable to Zones N.16 and N.17 based on the initial appearance of Globigerinoides extremus in Core 10 and those of Pulleniatina primalis and Globorotalia tumida plesiotumida in Core 8. The first occurrence of Globigerina nepenthes may suggest that Core 14 belongs in Zone N.14. Cores 11 through 14 are thus referable to Zones N.14 and N.15. Core 16 is assigned to Zones N.12 and N.13 on the basis of the limited occurrence of Globorotalia fohsi lobata. The concurrence of Globigerinoides sicanus and Globigerinatella insueta and the absence of the orbulines in Cores 18 and 19 indicate that they represent Zone N.8. The boundary between the lower and middle Miocene is drawn at the top of this zone. The N.6/N.7 boundary, which is indicated by the extinction of Catapsydrax unicavus unicavus and $C$. dissimilis dissimilis, lies within Core 20 . Although samples are not available to differentiate Zones N.5 and N.6 in the cores from Site 317, the $\mathrm{N} .4 / \mathrm{N} .5$ boundary is easily recognized as the level of the last occurrence of Globorotalia kugleri, both in Holes 317 (within Core 2) and 317B (between Cores 20 and 22).

The Oligocene/Miocene (Zones P.22/N.4) boundary is located between Cores 24 and 25, based upon the initial appearance of Globigerinoides quadrilobatus primordius. The Oligocene is represented by Cores 25 through 35 , and the Oligocene foraminiferal zones, P.18 to P.22, are clearly defined in the present section. Cores 25 through 28 are assigned to Zone P.22, the base of which is placed just above the extinction level of Globorotalia opima opima. Globorotalia galavisi and Globorotalia prasaepis disappear within the lower part of this interval, and Globorotalia kugleri appears first in the upper part. Cores 29 and 30 are referred to Zone P.21, based on the co-occurrence of Globorotalia opima opima and Globigerina angulisuturalis. The P.20/P.21 boundary is here placed between the horizon of the first occurrence of $G$. angulisuturalis and that of the last occurrence of Globorotalia ampliapertura, which marks the top of Zone P.20. Catapsydrax unicavus unicavus, shown by Blow (1969) to make its initial appearance at the P.19/P.20 boundary, occurs in Core 32 . Core 31 and the upper part of Core 32 (Section 2) are referred to Zone P.20., and contain a characteristic fauna consisting of 
species such as Cassigerinella chipolensis, Catapsydrax dissimilis ciperoensis, $C$. perus, C. unicavus unicavus, Globigerina angustiumbilicata, $G$. officinalis, Globoquadrina galavisi, G. sellii, G. tripartita tripartita, Globorotalia ampliapertura, G. prasaepis, Globorotaloides suteri, and Subbotina gortanii gortanii. The initial appearance of Globoquadrina sellii within the range of $G$. tripartita tapuriensis in Core 34 (though neither species is common) indicates that Cores 32 (only the lower part-Section 4) to 34 represent Zone P.19. Globoquadrina pseudovenezuelana, Pseudohastigerina micra, and Subbotina angiporoides have their uppermost occurrences within these cores.

The Eocene/Oligocene (P.17/P.18) boundary is drawn between Cores 35 and 37. Although the first occurrence of Subbotina gortanii gortanii, which is supposed to occur at the P.16/P.17 boundary, is observed at the same horizon, the presence of Cassigerinella chipolensis suggests that Core 35 is referable to Zone P.18. Section 2 of Core 36 represents probably Zone P.17, as indicated by the presence of Globigerina praebulloides leroyi and the absence of a number of species which characterizes the fauna of the underlying Zone P.16. The interval of Section 4 of Core 36 through Core 38 is assigned to Zones P.15 and P.16, based on the co-occurrence of Catapsydrax africanus, several species of Globigerinatheka, and Subbotina angiporoides. A large amount of faunal contamination was noted in Section 2 of Core 38, where numerous specimens of the Neogene species are found. The same type of downhole contamination was also observed in Core 29 , Section 4 , and Core 33, Section 2, although here it is less distinct. Cores 9 and 40 are judged to belong to Zone P.13 because of the co-occurrence of Globigerinatheka mexicana kugleri, Morozovella lehneri, and Truncorotaloides topilensis, and the absence of Globoquadrina tripartita tripartita. Accordingly, a stratigraphic break equivalent to Zone P.14 is estimated to occur between Cores 38 and 39, where the middle/upper Eocene boundary is placed.

\section{Site 318 (lat $14^{\circ} 49.63^{\prime} \mathrm{S}$, long $146^{\circ} 51.51^{\prime} \mathrm{W}$, depth 2659 m)}

Cores 1 through 31 represent discontinuous coring at Site 318, and include the sequence from lower Eocene to Pliocene. Well-preserved upper Neogene assemblages are present in Cores 1 to 8 , but moderate dissolution is obvious in Oligocene to middle Miocene assemblages of Cores 9 to 16. Strong dissolution has affected the Eocene assemblages of Cores 17 through 31 , and in some cases foraminifers have been completely removed.

The Pliocene is represented by Cores 1 to 5 , and the Miocene/Pliocene (N.17/N.18) boundary is placed between Cores 5 and 6 on the basis of the initial appearance of Globorotalia tumida tumida. No zonal subdivision was possible for the Pliocene section because of lack of sufficient zonal indexes. Core 7 is placed within Zone N.17, based on the presence of Globorotalia tumida plesiotumida in the lower section.
The boundary between Zones N.15/N.16 is drawn between Sections 2 and 4 of Core 7 based on the first occurrence of Globigerinoides extremus in Section 2. The presence of Globigerina nepenthes may indicate that Core 8 is referable to Zone N.14. A poorly preserved assemblage is found in Core 9, and is questionably referred to Zone N.9. The concurrence of Globigerinoides quadrilobatus altiaperturus and Globoquadrina binaiensis in Core 10 indicates placement in Zone N.5.

The Oligocene/Miocene (P.22/N.4) boundary is placed within Core 14, because the initial appearance of Globigerinoides quadrilobatus primordius is recorded in Section 1 of the core. Cores 11 through 14 (the upper part only), referred to Zone N.4, include Globorotalia kugleri and $G$. mendacis in addition to the abovementioned species. The Oligocene is represented by Cores 14 (Section 3) through 16. Although some reworked fossils are contained in the assemblage, the lower part of Core 14 may belong to Zone P.22. Core 15 is assigned to Zone P.20 on the basis of the cooccurrence of Catapsydrax unicavus primitivus and $C$. unicavus unicavus. Core 16 is provisionally assigned to Zone P.19, although all that can be said is that the core is not younger than this zone.

The Eocene/Oligocene boundary is tentatively drawn between Cores 16 and 17. As already stated, age assignment is extremely difficult for the Eocene section at Site 318 because of the strong effects of calcite dissolution. Moreover, many samples include reworked specimens. For these reasons, only a tentative age determination is made based on the following criteria. Core 17 may be placed within Zone P.15, as suggested by the presence of Catapsydrax africanus and Globigerinatheka mexicana mexicana. Although Core 20 is very poor in foraminifera, it is referred to Zone P.14, based on the assumption that Globigerinatheka senni and Morozovella lehneri make their last occurrence at this level. In a similar way, Cores 21 and 22 (Section 2) are referred to Zone P. 13, based on the assumed uppermost occurrence of Globigerinatheka mexicana kugleri and Truncorotaloides topilensis. The co-occurrence of Acarinina soldadoensis and Morozovella formosa indicates that Core 31 is referable to Zone P.7.

\section{REFERENCES}

Berggren, W.A., 1973. The Pliocene time scale: calibration of planktonic foraminiferal and calcareous nannoplankton zones: Nature, v. 243, p. 391-397.

Blow, W.H., 1969. Late middle Eocene to Recent planktonic foraminiferal biostratigraphy: In Brönnimann, P. and Renz, H.H. (Eds), Plankt. Microfossils, Int. Conf. 1st, Pros.: Leiden (Brill), v. 1, p. 199-422.

Fleisher, R.L., 1974. Cenozoic planktonic foraminifera and biostratigraphy, Arabian Sea Deep Sea Drilling Project, Leg 23. In Whitmarsh, R.B., Weser, O.E., Ross, D.A., et al., Initial Reports of the Deep Sea Drilling Project, Volume 23: Washington (U.S. Printing Office), p. 10011072. 